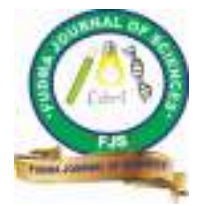

FUDMA Journal of Sciences (FJS)

ISSN online: $2616-1370$

ISSN print: 2645 - 2944

Vol. 4 No. 3, September, 2020, pp 531-537

DOI: https://doi.org/10.33003/fjs-2020-0403-303

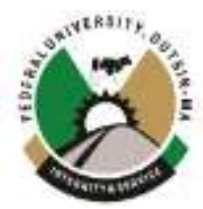

\title{
ASSESSMENT OF SELECTED HEAVY METALS IN DRINKING WATER CONSUMED WITHIN KATSINA
} METROPOLIS

\author{
${ }^{* 1}$ Yusuf Abdulrashid and ${ }^{2}$ Nuraddeen Abdurrahman \\ ${ }^{1}$ Scientific Department, Technology Incubation Centre Gusau, National Board for Technology Incubation, Federal Ministry of \\ Science and Technology, Garki-Abuja, Nigeria \\ ${ }^{2}$ Department of Pure and Industrial Chemistry, Umaru Musa Yar'adua University, Katsina State, Nigeria \\ *Corresponding Author's Email: abdulsujee@yahoo.com
}

\begin{abstract}
The study involved the analysis of some selected heavy metals in drinking water consumed within Katsina Metropolis. The water samples were collected from Ajiwa dam raw water, taps, wells, boreholes, and sachet waters and the concentration of heavy metals $(\mathrm{Cd}, \mathrm{Pb}, \mathrm{Cr}, \mathrm{Co}$, and $\mathrm{Ni}$ ), was determined using Atomic Absorption Spectrophotometer (AAS). The results obtained from the water analysis indicate that cadmium was not found in all the water samples. The concentrations range for lead were $(6.222-109.63) \mu \mathrm{g} / \mathrm{L}$ with maximum concentration value of $109.63 \mu \mathrm{g} / \mathrm{L}$ in Ajiwa dam raw water, above the World Health Organization (WHO) limit, nickel (0.72-6.99) $\mu \mathrm{g} / \mathrm{L}$ with maximum concentration value of $6.99 \mu \mathrm{g} / \mathrm{L}$ in borehole water, within WHO limit, chromium (36-72) $\mu \mathrm{g} / \mathrm{L}$ with maximum concentration value of $72 \mu \mathrm{g} / \mathrm{L}$ in well water, above WHO limit, cobalt (4.758-9.516) $\mu \mathrm{g} / \mathrm{L}$ with maximum concentration value of $9.516 \mu \mathrm{g} / \mathrm{L}$ in well water, within WHO limit. The results indicate that most of the concentrations of the heavy metals determined were within the WHO limit, except for chromium in well water which may arises from the Government activities of money recycling and incineration of old bank notes which does not affect other water sources in the area and lead in Ajiwa dam raw water which was further removed through water treatment processes. Moreover, the Analysis of Variance (ANOVA) indicate no significant difference in the means of the heavy metals concentrations in all the water samples analyzed, and this may be due to the same physicochemical factors and limited industrial activities in the study area.
\end{abstract}

Keywords: Heavy Metals, Drinking water, Spectrophotometer, Concentration, WHO.

\section{INTRODUCTION}

Water is one of the essential components of the physical environment, it is estimated that water covers almost $70 \%$ of the earth's surface .Water compose of oxygen and hydrogen in a ratio of 1:2 which can be photo-dissociated by ultraviolet radiation to yield hydrogen ion $\left(\mathrm{H}^{+}\right)$and hydroxide ion $\left(\mathrm{OH}^{-}\right)$ in the stratosphere (Ademoroti, 1996). Pure water is usually colorless, clear, tasteless and odorless, it boil and frozen at temperature of $100{ }^{\circ} \mathrm{C}$ and $0{ }^{\circ} \mathrm{C}$ respectively. Basically, water can be categorized into three, according to their main sources; as rain water, surface water and underground water sources. Furthermore, water is among the most essential substances needed to maintain human, animals, and plants life (Vermani and Narula, 1989). It is needed for drinking, cooking, bathing, washing of domestic and human waste etc. (Marr and Crasser, 1983). Water is also the major constituent of the body, which account for about $70-80 \%$ of weight of most tissues like muscles, brain, liver, and more. It is estimated the average water content of a body as a whole is about $61 \%$ in a normal adult (ASAE, 1979). Various meanings have been assigned to heavy metals. Thus it can be defined as a subset of elements that exhibit metallic properties which comprises the transition metals, few metalloids, lanthanides and actinides. Density was also used as a defining factor in many reports. Thus heavy metals are those metals having a specific density of $5 \mathrm{~g} / \mathrm{cm}^{3}$ or more (Jarup, 2003). They were also defined as chemical elements with the density greater than $4 \mathrm{~g} / \mathrm{cm}^{3}$ found in all kinds of rocks, soils and water in fresh water ecosystem and terrestrial habitat (Suciu et al., 2008). Moreover, they can also be referred to as any metallic elements that have relatively high density and toxic even at lower concentrations (Adelekan and Abegunde, 2011). Furthermore, they are chemical elements with a specific gravity that is at least 5 times the specific gravity of water (Lenntech, 2010; Obodai et al., 2011; Yahaya et al., 2012).

\section{MATERIALS AND METHODOLOGY}

It was ensured that analytical grade reagents and deionized waters were used in this research this was to avoid unnecessary contaminations. Glass wares were thoroughly washed with detergent and rinsed with deionized water and dried in an oven at $105^{\circ} \mathrm{C}$ and water samples were analyzed using Atomic Absorption spectrophotometer (AAS).

\section{Sampling and Samples Collection}

The samples of well, borehole and sachet waters were collected each at different locations within Katsina metropolis. In addition to these, tap and Ajiwa dam raw waters were also collected for the analysis of heavy metals. The samples were collected in well cleaned 5 litres polythene plastic containers and the sample containers were rinsed with their respective water samples before filling each.

The samples of boreholes and tap waters were collected at 3 
hours intervals thrice daily, the tap water was allowed to run for few minutes before filling into the sample containers so as to obtain a composite sample as recommended by (Oporaocha et al., (2010). The sachet waters were purchased from the popularly patronized brands at different locations in Katsina metropolis, two sachets out of every bag of the same brand of water were sampled and total of 20 sachets were transferred into 5 liter plastic containers so as to form a representative of the whole. The same procedure was applied to other brands in all the study areas.

Well water were sampled from different locations using hand pump and also collected at 3 hours intervals thrice daily in order to form a representative sample of the whole. Each of the samples was labeled immediately after collection as recommended by (Oporaocha et al., 2010).

\section{Research Area}

The Katsina State is located in Northern Nigeria and lies between latitude of $12^{\circ} 59^{\prime} 26.95^{\prime \prime} \mathrm{N}$ and longitude of $7^{\circ} 36^{\prime}$ 6.37 " E with an estimated area of $24,1929 \mathrm{~km}^{2}$ and estimated population of $3,878,344$ as of 1991 census. It shares the borders from east with Kano State and Jigawa States, from the west with Zamfara state, and from the north with Niger Republic. (Nigeria galleria.com 2009). The state is among the few states in Nigeria where both the rainy and dry season farming take place

\section{Identification of Sampling Areas}

Table 1: The Table below shows identification of sampling sites

\begin{tabular}{lll}
\hline S/NO & $\begin{array}{l}\text { Sampling sites from Katsina and Batagarawa local } \\
\text { government }\end{array}$ & Sample I.D \\
\hline $\mathbf{1}$ & Kambarawa Well & KW \\
$\mathbf{2}$ & Kambarawa Borehole & KB \\
$\mathbf{3}$ & Kambarawa sachet & KS \\
$\mathbf{4}$ & Kofar Sauri Well & KSW \\
$\mathbf{5}$ & Kofar Sauri Borehole & KSB \\
$\mathbf{6}$ & Kofar Sauri sachet & KSS \\
$\mathbf{7}$ & Dutsen safe Well & DSW \\
$\mathbf{8}$ & Dutsen safe Borehole & DSB \\
$\mathbf{9}$ & Dutsen safe sachet & DSS \\
$\mathbf{1 0}$ & Tudun mattawalle Well & TMW \\
$\mathbf{1 1}$ & Tudun matawalle Borehole & TMB \\
$\mathbf{1 2}$ & Tudun matawalle sachet & TMS \\
$\mathbf{1 3}$ & Tap water & TW \\
$\mathbf{1 4}$ & Ajiwa treated water & ATW \\
$\mathbf{1 5}$ & Ajiwa Dam Raw Water & ADW \\
\hline
\end{tabular}

\section{Sample Preparations for Analysis}

The collected samples were first boiled to $100{ }^{\circ} \mathrm{C}$ and allowed to settle, it was then decanted. 5 liters each of the decanted water sample was measured and transferred to a cleaned pot for evaporation. When the volume of the sample reached about 30 $\mathrm{ml}$ it was then transferred into a Pyrex beaker and evaporated to dryness.

The resulting residues were then leached with $30 \mathrm{~cm}^{3}$ of 0.5 $\mathrm{mol} / \mathrm{dm}^{3} \mathrm{HNO}_{3}$ later filtered into $30 \mathrm{ml}$ sample bottle. $25 \mathrm{~cm}^{3}$ of the solution were used for the determination of $(\mathrm{Cd}, \mathrm{Co}, \mathrm{Pb}$, $\mathrm{Ni}$, and $\mathrm{Cr}$ ).

\section{Preparation of stock solutions}

Cadmium: $1000 \mathrm{mg} / \mathrm{L}$

$2.1033 \mathrm{~g}$ of Cadmium nitrate $\mathrm{Cd}\left(\mathrm{NO}_{3}\right)_{2}$ were dissolved in $1000 \mathrm{~cm}^{3}$ flask and made to the mark with $0.5 \mathrm{M} \mathrm{HNO}_{3}$.

Lead: $1000 \mathrm{mg} / \mathrm{L}$

$1.5986 \mathrm{~g}$ of $\left(\mathrm{Pb}\left(\mathrm{NO}_{3}\right)\right.$ were dissolved in $1000 \mathrm{~cm}^{3}$ flask and made to the mark with $0.5 \mathrm{M} \mathrm{HNO}_{3}$

Cobalt: $1000 \mathrm{mg} / \mathrm{L}$

$4.038 \mathrm{~g}$ of $\mathrm{CoCl}_{2} .6 \mathrm{H}_{2} 0$ were dissolved in $1000 \mathrm{~cm}^{3}$ flask and made to the mark with $0.5 \mathrm{M} \mathrm{HNO}_{3}$.
Chromium: $1000 \mathrm{mg} / \mathrm{L}$

$3.3852 \mathrm{~g}$ of $\mathrm{Cr}\left(\mathrm{NO}_{3}\right)_{2}$ were dissolved in $1000 \mathrm{~cm}^{3}$ flask and made to the mark with $0.5 \mathrm{M} \mathrm{HNO}_{3}$

\section{Nickel: 1000 mg/L}

$4.0499 \mathrm{~g}$ of $\mathrm{NiCl}_{2} .6 \mathrm{H}_{2} \mathrm{O}$ were dissolved in $1000 \mathrm{~cm}^{3}$ flask and made to the mark with $0.5 \mathrm{M} \mathrm{HNO}_{3}$

\section{Calibration standards for the metals}

Preparation of 100ppm Standard Solution

$10 \mathrm{~cm}^{3}$ of $1000 \mathrm{ppm}$ multi element stock solution were measured into $100 \mathrm{~cm}^{3}$ flask and made to the mark with $0.5 \mathrm{M}$ $\mathrm{HNO}_{3}$.

\section{Preparation of $2.5 \mathrm{ppm}$ Standard Solution}

$2.5 \mathrm{~cm}^{3}$ of $100 \mathrm{ppm}$ multi element stock solution were measured into $100 \mathrm{~cm}^{3}$ flask and made to the mark with $0.5 \mathrm{M}$ $\mathrm{HNO}_{3}$. The absorbance reading for the metals $(\mathrm{Cd}, \mathrm{Co}, \mathrm{Pb}, \mathrm{Ni}$, and $\mathrm{Cr}$ ) were taken by atomic absorption spectrophotometer (AAS).

\section{RESULTS AND DISCUSSION}

Results

The concentrations of 5 heavy metals were analyzed in their samples' solution by atomic absorption spectrophotometer (AAS) and the results obtained were compared with the (WHO 2011) standard limit for drinking water as shown below; 
Table 2: Results of Water Samples Analyzed in $(\mu \mathrm{g} / \mathrm{L})$

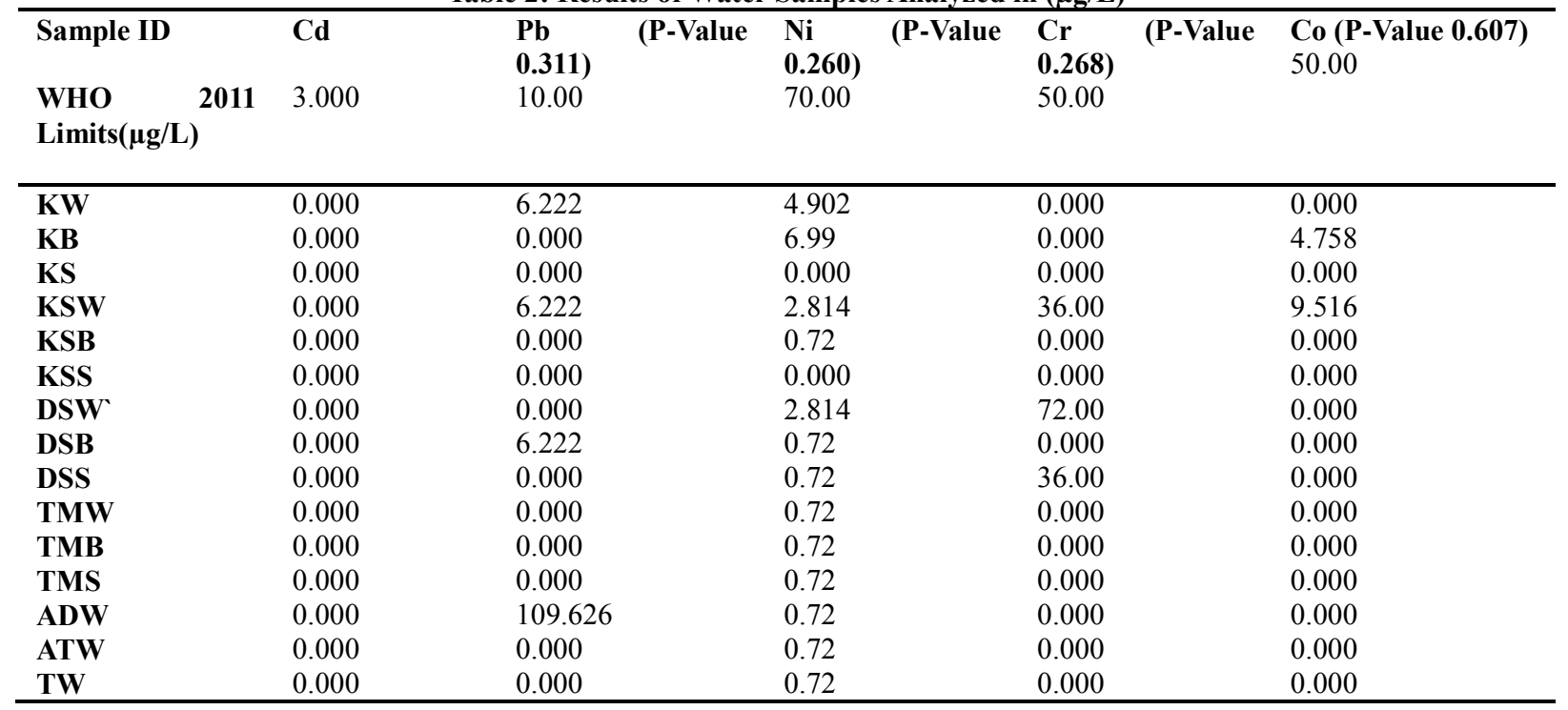

\section{DISCUSSION}

Cadmium

From the result obtained, there was zero cadmium concentration in all the water samples analyzed. This may be as a result of the physicochemical properties of the soil and the limited industrial activities in the study area, such as mining and other petroleum refining activities.
The zero concentration of the metal shows that water samples were within the limit set by WHO. Cadmium is among the poisonous heavy metals that are not needed by the living organisms, thus when accumulated into plants or human beings may leads to growth disorder, serious health challenges and possible death.

\section{Lead}

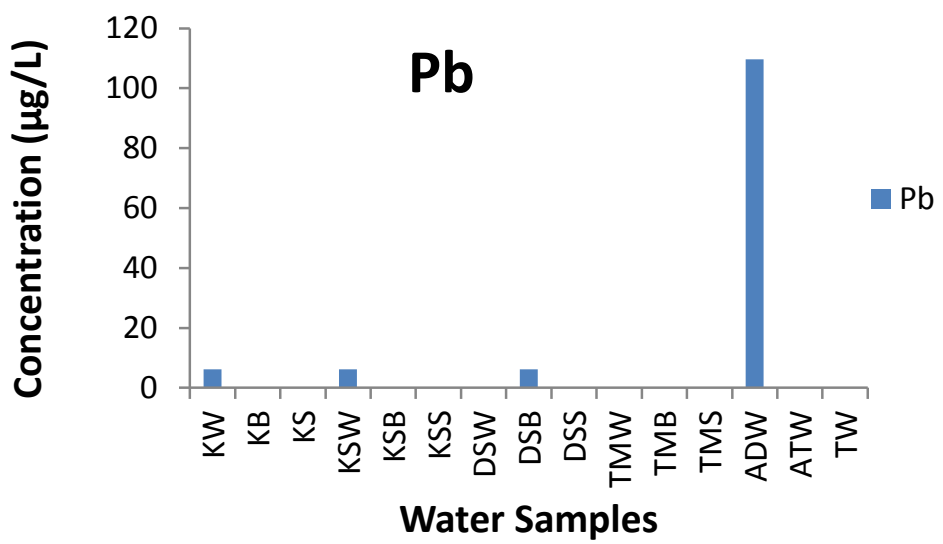

Figure 1: Lead concentration in the water samples

The lead concentration ranged between (6.222-109.63) $\mu \mathrm{g} / \mathrm{L}$, as shown in the figure 1

Lead was observed at the highest level in the Ajiwa dam raw water, while zero concentration of lead was observed in the sachet and tap waters samples.

It can be seen that lead were detected in trace amount at Kambarawa and Kofar Sauri well waters; this may be attributed by the physicochemical properties of the soils and dissolution of this metal from its natural sources in the water. Furthermore, the presence of lead in Dutsen Safe borehole water may be largely contributed from the corrosion of pipes or coating in the plumbing materials or by other physicochemical properties of the soil in the area.

Except for Ajiwa dam raw water, the concentration of lead in the water samples analyzed were all within the standard limit set by WHO. The presence of Lead in Ajiwa dam raw water may be as a result of wastes from different sources ranging from the use of fertilizers for farming in the rainy season, irrigation farming, household effluents and dissolution of the metal from it source in the water. 
Nickel

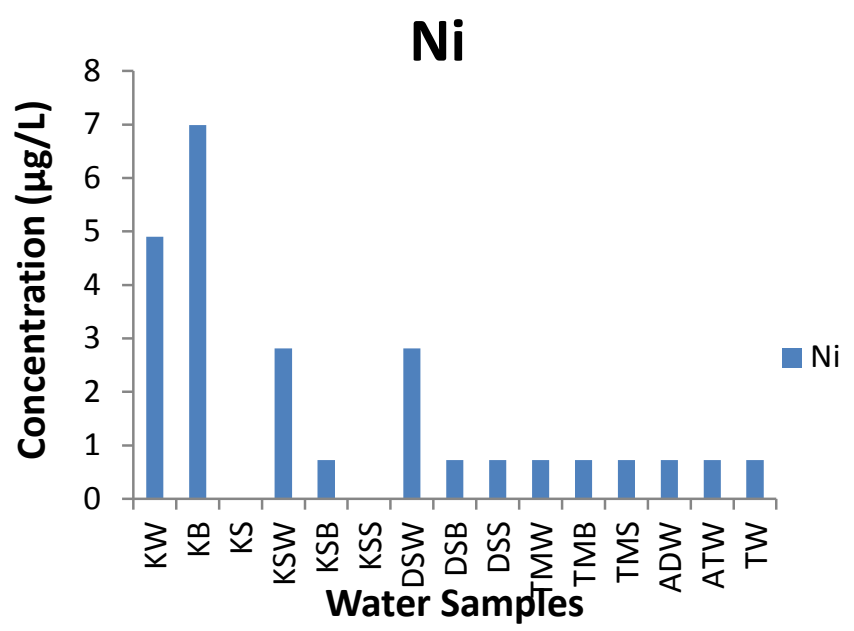

Figure 2: Nickel concentration in the water samples

Nickel concentration ranged between $(0.72-6.99) \mu \mathrm{g} / \mathrm{L}$, as shown in figure 2 .

Borehole water was found with the highest nickel concentration, while zero concentration of nickel was observed in most of the sachet water analyzed.

The concentrations of nickel in all water samples analyzed were within WHO limit for nickel in drinking water.

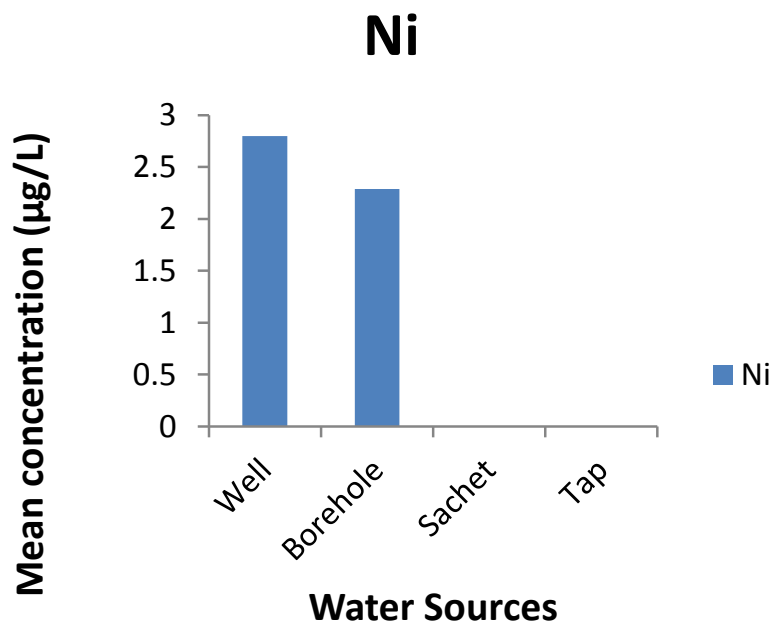

Figure 3: Distribution of nickel concentration in water samples analyzed from different sources

Nickel is needed in living organisms' wellbeing, but may be nickel concentration was observed in borehole water samples. poisonous or carcinogenic when taken in an excess dose. In It is clearly shown that most of the nickel concentrations were this study, well water was found to have the highest mean between well and borehole water samples which does not affect nickel concentration from the water sources, and the least mean the quality of water in the area. 


\section{Chromium}

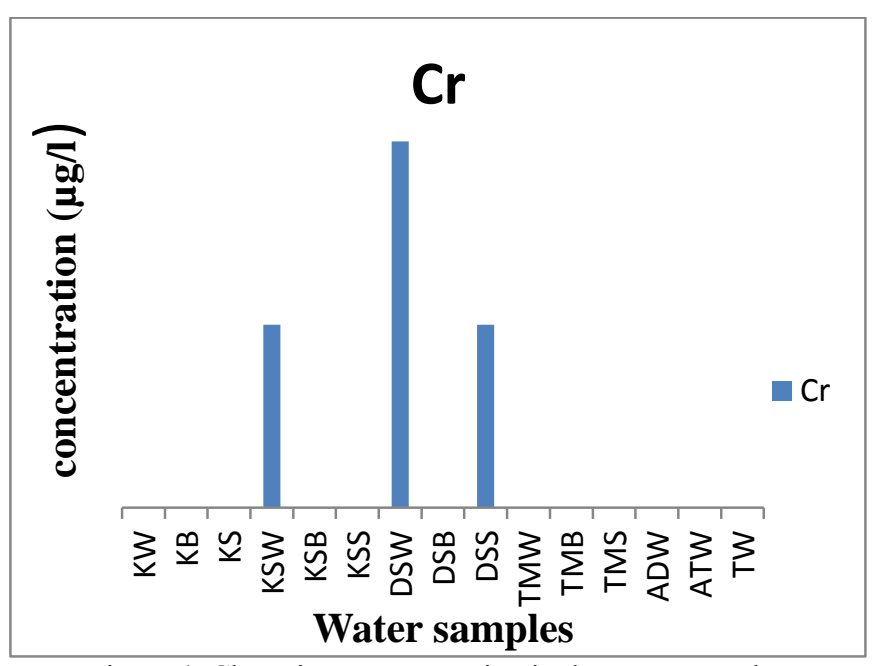

Figure 4: Chromium concentration in the water samples

Chromium concentration ranged between (36-72) $\mu \mathrm{g} / \mathrm{L}$ as shown in figure 4.

Well water was found to have the highest concentration of chromium and zero concentration of chromium was observed in the borehole, tap and Ajiwa dam raw waters.

The highest concentration of chromium was observed in Dutsen Safe well water sample was above the standard limit set by WHO, this may be as a result of Government activities of incineration of old bank notes in the area. While chromium in
Kofar Sauri well water sample was found within WHO limit. Furthermore; chromium in the Dutsen Safe sachet water sample was found within the standard limit set by WHO. It can be seen that the sachet water containing chromium were from the same area with the highest chromium concentration in the well water samples, so the water company may have being using the well water for their processes. It was further observed that the concentration was drastically reduced after treatment to the limit set by WHO.

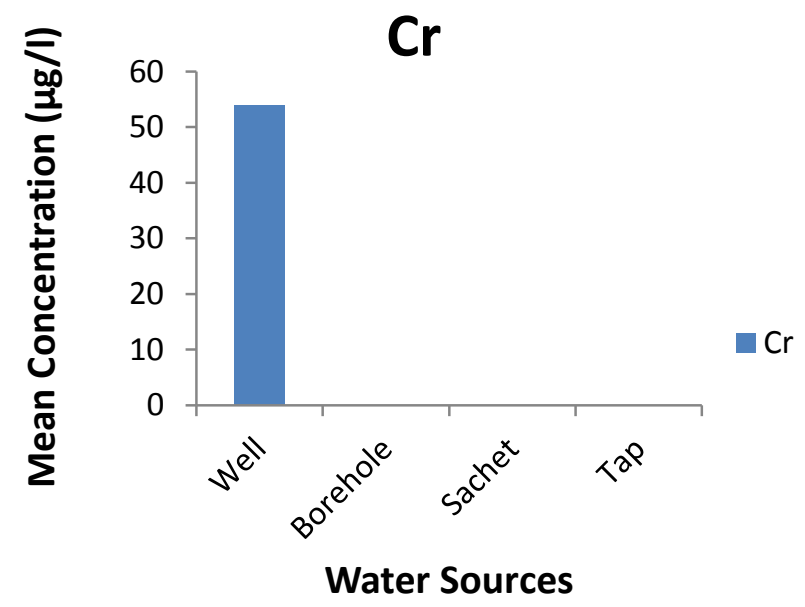

Figure: 5 Distribution of chromium concentration in the water samples analyzed from different sources

Well water samples were found to have the highest chromium mean concentration from the water sources in the study area and the least mean chromium concentration was observed in the sachet water sample. This means the chromium concentration does not affect the other water sources in the area. 
Cobalt

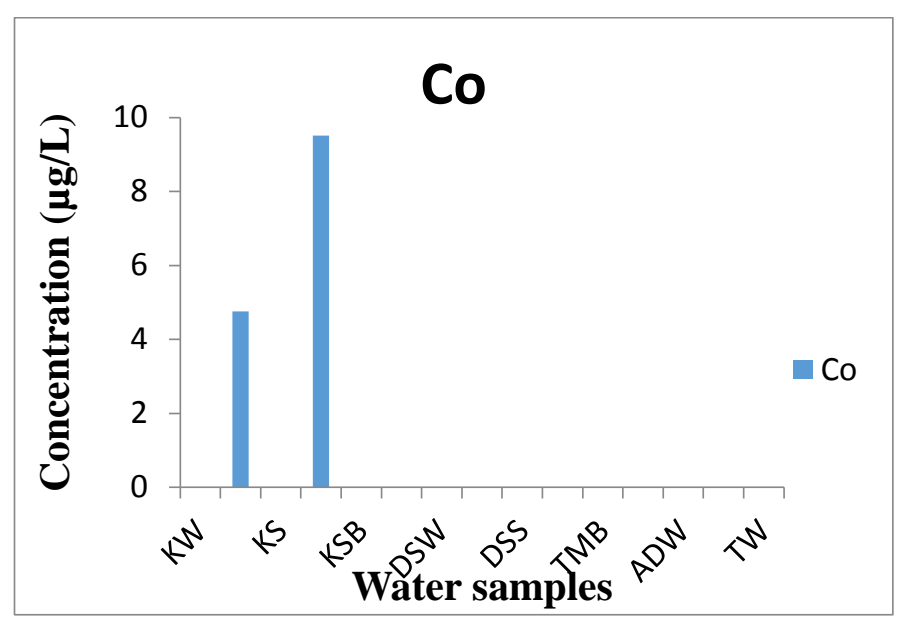

Figure 6: Cobalt concentration in the water samples

Cobalt concentrations were ranged between (4.758-9.516) $\mu \mathrm{g} / \mathrm{L}$, as shown in the figure 6 .

Kofar Sauri well water was found to have the highest cobalt concentration and the least concentration was observed in the Kambarawa borehole water. Zero concentration of cobalt was observed in the sachet, tap and Ajiwa dam raw waters.

The concentration of cobalt in all the water samples was found within WHO standard limit for drinking water. This indicates that the water may be safe for drinking.

Cobalt is known to be essential for the body of human beings, but when taken in an excess may lead to health challenges such as (pneumonia, asthma and many more).

\section{Analysis of Variance}

From the analysis of variance (ANOVA), it can be seen that the p-values of each heavy metal analyzed was found above the $\propto$ -value of 0.05 which shows there is no significant difference in the means of the heavy metals concentration in their respective water samples analyzed. This may be due to the fact that water samples came from almost same geographical locations and may exhibit the same physicochemical properties, and the study area is not much affected by industrial activities that usually contribute to heavy metals accumulations in the water.

\section{CONCLUSION}

Based on the results obtained, it can be concluded the water in these locations can be used for domestic purposes such as drinking, washing, bathing, irrigation, fishing, industrial purposes and many more, because the level of these metals in drinking water pose no any health hazards for now. However, the level of these heavy metals in Ajiwa Dam raw water and some borehole waters are rising to a level that may cause some health problem and consumer acceptability if care is not taken. It is therefore recommended that the government and other concern individuals can impose laws that can minimize the discharge of some agricultural wastes and other sources that may cause increase in the level of the heavy metals concentration; hence their higher concentration in the waters may be minimized.

\section{REFERENCES}

Adelekan B. A. and Abegunde K. D. (2011).Heavy Metals Contamination of Soil and Groundwater at Automobile Mechanic Villages in Ibadan, Nigeria. International Journal of the Physical Sciences vol. 6(5), pp. 1045-1058

Ademoroti, C.M. (1996): Standard Method for water and Effective Analysis. $1^{\text {st }}$ edition, March Prints and consultancy, Ugbowo Estate, Benin, Pp. 27 - 43.

American Society of Agricultural Engineers (ASAE) (1979). Quality Water for the Home at Farm:Proceedings of the Third Domestic Water Quality Symposium. Publication 1-79.

Jarup, L. (2003). Harzards of heavy metal contamination.British Medicine Bulletin, 68: 167 - 182.

Katsina State of Nigeria. Nigeria galleria.com (2009): Nigeria Information guide. Nigeria BusinessIndex; 2009. Available: http://www.nigeriagalleria.com/Nigeria/Statesfree

Nigeria/Katsina State.

Lenntech (2010). Heavy Metals. www.lenntech.com. Accessed on 2nd July, 2012. pp.1-3.

Marr, I.L. and Crasser, M.S.(1983). Environmental Chemical Analysis, International Textbook Company, New York. Pp 23 39.

Oparaocha, E. T.; Iroegbu, O. C.; Obi, R. K.; (2010): Assessment of the Quality of Drinking Water Sources, Journal of Applied Biosciences 32: 1964 - 1976

Suciu I., Cosma C., Todica M., Bolboaca S.D. and Jantschi L. (2008).Analysis of Soil Heavy Metal Pollution and Pattern in Central Transylvania. International Journal of Molecular Sciences, 9(4) : 434-453.

Vermani, O.P. and Narula, A.K. (1989), Applied Chemistry, Theory and practice Page $34-81$. 
WHO (2011), World Health Organization Guidelines for Drinking water Quality, $4^{\text {th }}$ Edition Geneva, Switzerland.

Yahaya A., Adegbe A. A. and Emurotu J. E. (2012).
Assessment of Heavy Metal content in the Surface Water of Oke-Afa Canal Isolo Lagos, Nigeria. Archives of Applied Science Research, 4(6), pp. 2322-2326.

$\mathrm{s}$ 